\title{
ADAPTATION, ASSOCIATION, AND ANALOGY: TRIPLE A OF THE TRANSLATOR'S DECISION-MAKING
}

\author{
Oleksandr Rebrii \\ rebrii1967@gmail.com \\ https://orcid.org/0000-0002-4912-7489 \\ Scopus Author ID: $\underline{57197723276}$ \\ V.N. Karazin Kharkiv National University, Ukraine \\ Vladyslava Demetska \\ https://orcid.org/0000-0001-9902-7913 \\ vdemetskaya@gmail.com \\ Kyiv National Linguistic University, Ukraine
}

Received May 3, 2020; Revised July 8, 2020; Accepted September 14, 2020

\begin{abstract}
The article is dedicated to the analysis of concurrent verbalizations (also known as Think-Aloud Protocols, or TAPs) of semi-professional subjects of the introspective experiment based on the initial fragment of Steven Brust's fantasy novel The Desecrator. The research was conducted on the basis of activity-oriented approach within which translation is treated as an integrated cognitive process that unites perceptive, interpretative and productive operations. The participants of the experiment were students for Master's Degree in Translation at the School of Foreign Languages of V. N. Karazin Kharkiv National University, Ukraine. The choice was determined by the fact that the subjects of this type have a high level of a foreign language competence as well as sufficient theoretical background in translation, while, at the same time, they lack practical experience which requires from them considerable psycho-cognitive and creative effort for decision-making in ambiguous situations. The aim of the research is to determine the role of adaptation, association and analogy in resolving problem situations in translation. Adaptation, association and analogy were highlighted as both psychological mechanisms and cognitive procedures of the translator's decision-making. The psychological function of adaptation lies in bringing the translator to the state of adaptivity by applying available knowledge to new situations; its cognitive function lies in adjusting new or alien to the target audience concepts in accordance with the translator's individual worldview. Psychocognitive function of association is twofold: firstly, the translator is expected to decipher and reproduce associations underlying the author's decisions; secondly, the translator's own decisions are often of associative nature. Analogical reasonings substantiate the translator's choices through similarity-based heuristics, like those of representativeness and compatibility. The research allowed to expose some varieties of psycho-cognitive mistakes and to express the assumption that the translator's erroneous decisions are ensued by the malfunctioning of the above mechanisms, i.e. by incorrect adaptations, associations, analogies.
\end{abstract}

Keywords: adaptation, analogy, association, psycho-cognitive mechanisms and procedures, translation methodology, translator's decision-making.

(C) Rebrii, Oleksandr, Demetska, Vladyslava, 2020.

This is an Open Access article distributed under the terms and conditions of the Creative Commons Attribution 4.0 International Licence (http://creativecommons.org/licenses/by/4.0). East European Journal of Psycholinguistics, 7(2), 231-242. https://doi.org/10.29038/eejpl.2020.7.2.reb 


\section{Олександр Ребрій, Владислава Демецька. Адаптація, асоціація та аналогія: три важливих механізми прийняття рішень в перекладі. \\ Статтю присвячено аналізу паралельних вербалізацій (також Протоколи Міркуй} Уголос або ПМУ), отриманих від напівпрофесійних інформантів в перебігу перекладу початкового уривку фентезійного роману Стівена Браста "The Desecrator". Дослідження здійснено із застосуванням діяльнісно-орієнтованого підходу, 3 перспективи якого переклад розглядають як інтегрований когнітивний процес, що об'єднує перцептивні, інтерпретаційні та продукційні операції. Учасниками експерименту були студенти Харківського національного університету імені В.Н.Каразіна (Україна). Такий вибір зумовлено тим фактом, що ці суб'єкти мають і високий рівень компетентності в іноземній мові, і достатні теоретичні знання в перекладі, хоча й мають недостатній рівень практичного досвіду, який вимагає від них значних психо-когнітивних та творчих зусиль для прийняття рішень у ситуаціях неоднозначності. Метою дослідження є визначення ролі адаптації, асоціації та аналогії у вирішенні проблемних ситуацій в перекладі. Адаптацію, асоціацію та аналогію було висвітлено як психологічні механізми та когнітивні процедури прийняття перекладацьких рішень. Психологічна функція адаптації полягає у приведенні перекладача до стану адаптивності за рахунок використання наявних знань щодо нових ситуацій; іï когнітивна функція полягає у пристосування нових або непритаманних цільовій аудиторії концептів у відповідності до індивідуальної картини світу перекладача. Психокогнітивна функція асоціації $є$ подвійною: по-перше, очікується, що перекладач здатен розшифрувати та відтворити асоціації, що перебувають в основі рішень автора; подруге, його власні рішення часто мають асоціативну природу. Міркування на основі аналогії визначають перекладацький вибір за допомогою евристик подібності, таких як евристика репрезентативності та евристика сумісності. Дослідження дало змогу виявити психокогнітивні типи помилок, спричинених порушенням дії зазначених механізмів.

Ключові слова: адаптація, аналогія, асоціація, методологія перекладу, перекладацькі рімення, психокогнітивні механізми і процедури.

\section{Introduction.}

Translator's decision-making remains largely underinvestigated in its many aspects (among pioneers in this field Jirí Levý (Levý, 2000) and Katharina Reiss (Reiss, 2000) should be mentioned), in particular, our ideas of cognitive procedures and psychological mechanisms underlying this process are still vague and based more on assumptions than on firm evidence. However, hundreds of scientists all over the world have been making an attempt after attempt to take the lid off the black box of the translator's mind: "Though valuable research exists in this area, it remains highly fragmented; and certain aspects appear to have been off-limits to direct empirical research" (Jones, 2006, p. 59).

Since translation has long been acknowledged as "an integrated cognitive process that combines mental operations of perception, interpretation, comprehension and production" (Zasiekina \& Zasiekin, 2002, p. 101), the above efforts go hand in hand with a challenge of a much greater scale - to determine and investigate the ties between human mind, language and speech production which is precisely the area of responsibility for psycholinguistics. Thus, the aim of our research is to describe how general psychological mechanisms and, simultaneously, cognitive procedures of adaptation, association and analogy that regulate various manifestations of human behavior and thinking reveal themselves through the use of language in translation as a variety of speech and form of communication. Consequently, these mechanisms/procedures can be defined as the object of our research, while its subject is twofold: firstly, it is linguistic forms of externalizing adaptation, association and analogy in translation; secondly, it is various indications of the role and function of adaptation, association and analogy in translation as retrieved from concurrent verbalizations of the translators' decision-making. 


\section{Methodology}

The research is based on the strong belief that experimental method borrowed by translation studies from psychology and known as Think-Aloud Protocols (TAPs) can provide some indirect but rather insightful information as to the psycholinguistic substantiation of decision-making in translation. To this end, we designed and held an introspective TAP-type experiment in which 6 subjects gave concurrent verbalizations of their thoughts and considerations that came to their minds during the translation of a fiction text, namely, initial fragment (circa 2800 printed characters) from Steven Brust's fantasy novel "The Desecrator". The analysis of the subjects' reports together with their translations allowed to trace down how adaptation, association and analogy are manifested in problem situation to which we refer those concurrences of circumstances that do not have an unambiguous solution. Some erroneous decisions of the experiment's subjects turned out useful for exposing psycho-cognitive types of mistakes that beginner translators are prone to.

Though TAPs have been in active use in translation studies since the 1980s, their validity as to obtaining reliable cognitive/psycholinguistic data is still under question for fear of possible reactivity and incompleteness (Rojo, 2015). In response to these claims, Karl Anders Ericsson and Herbert Alexander Simon explained in their information processing model that "according to this verbal report procedure the new incoming information is maintained in attention until the corresponding verbalization of it is completed. The crucial aspect of this procedure is that the sequence of states, i.e. the information contained in attention and STM [Short-Term Memory - O.R. V.D.], remains the same with the verbal report procedure as it would be without the reporting procedure" (Ericsson, Simon, 1987, p. 32). The only observable difference between verbalized and non-verbalized taskcompleting is that "participants would take somewhat longer to complete the tasks while thinking aloud - presumably because of the additional time required for completing the overt vocalization of the verbal expression of the thoughts" (Ericsson, 2003, p. 10). Translation-wise, this difference seems irrelevant.

\section{Results and Discussion}

The $1^{\text {st }}$ psychological mechanism of the translator's decision-making that falls in the focus of our attention is adaptation. In regard to translation, adaptation is usually treated as a strategy aimed at "directing information towards the culture of the consumer and making adjustments according to the general tastes of consumers of that culture" (Milton, 2009, p. 51-52). As a translation technique / method / procedure, adaptation is defined as "the extreme limit of translation", that is "used in those cases where the type of situation being referred to by the SL message is unknown in the TL culture. In such cases translators have to create a new situation that can be considered as being equivalent. Adaptation can, therefore, be described as a special kind of equivalence, a situational equivalence" (Vinay, Darbelnet, 
1995, p. 39). What is more important, "in the context of comprehending the translator's adaptation, determining the boundaries of its application, the role of the translator's individual 'psycholinguistic presence' in a target text acquires supreme importance" (Demetska, 2019, p. 76).

Our view of adaptation is drastically different as it is aimed at exposing its role in translation as a psychological mechanism that leads an individual to the state of adaptivity as a result of conducting a successful and productive activity. In psychology, such an activity is known under the term 'adaptive behavior' understood as "those skills learned throughout development and performed in response to the expectations placed on us from our community and society at large" (Tasse, 2013). Thus, adaptation is "the process of restructuring problem situations by finding a new structural integrity" (Nalchadzan, 2009, p. 82). The level of creative input in adaptation processes varies: it can be lower for typical problem situations (those requiring standard solutions or those the translator is accustomed to) or higher for atypical problem situations that fall under umbrella term 'translation difficulties'. In the latter case, adaptation is characterized as 'innovative' or 'creative' because it refers to those human activities that result in the creation of new values and introduce innovations into particular areas of culture. This understanding of adaptation correlates with peculiar to modern translation studies views of translation as a (relatively) independent creative activity.

Let us consider the following example: It was early in the morning of the third day of the month of the Phoenix in the 230th year of the Reign of Her Glorious Majesty Zerika the Fourth that you sent me to meet the desecrator (Brust, The Desecrator).

Quite naturally, the subjects faced considerable difficulties with both interpreting and reproducing such fictitious names as (the month of the) Phoenix and (Her Glorious Majesty) Zerika the Fourth. As a result, they aspired to adapt the names from an alternative world to those from the real one, since "one cognitive and practical way humans explore the new is by flavoring it with the old, the familiar" (Schulkin, 2009, p. 56). As Jay Schulkin points out, "naming objects marking them and keeping track of them over time - is a fundamental feature of linguistic expression and a form of cognitive adaptation" (ibid.).

See, for instance, Protocol \# 2: "Month of the Phoenix так і лишимо "місяця фенікса'. В наших історичних реаліях, хоча така птиця, яка володіла здібностями класичного фенікса, у західній міфології мала інше дещо ім'я 'Жарптиця', але зараз усі знають, хто такий 'фенікс' і, мабуть, це не викличе ніяких перешкод розумінню".

Protocol \# 3: "Місяць Фоенікс, ні Фенікс, місто в США, штат Арізона, значить автор на щось натякає, але мені поки незрозуміло. <..> Значить, ми з'ясували, що “Зеріка” - це єврейський мудрець, а 'четвертий'? Тепер у реченні вже все з'ясовано, знайомо, окрім місяця: чому саме його так назвали. 
Ну, я вважаю, що можна залишити і 'фенікс'. Чомусь Вікіпедія видає 'Зеріка' як чоловіка, чому тут це жінка - також питання. Це мене збило з пантелику. Так... дивно, чому 'Зеріка' жіночого роду, ну нехай. <..> Так, але мені не дуже подобається".

Protocol \# 5: ““Спозаранку третього дня місяця Фенікса', я думаю, так і залишимо 'місяця Фенікса', хоча, можливо, потрібно робити інтерпретацію, що таке Фенікс, але я думаю, на сьогоднішній час уже немає в цьому потреби i навіть дитина знає, що значить Фенікс. Багато літератури про це все - i фільми, і все, що хочеш. <..> так... і далі ми маємо власну назву $H E R$ GLORIUOS MAJESTY ZERIKA, тобто має бути ім'я або королеви, або можливо якоїсь принцеси, тобто давайте це перекладемо - 'іiі величності'. А як щодо перекладу назви? Чи правильно це взагалі буде українською мовою? 'Зеріка' чи 'Зеріка'? (зміна наголосу), але мені чомусь здається, що на переклад цього імені наголос потрібно ставити на перший склад, так як асоціації лише 3 zero - 'нуль'. Тобто - 'Зеріка'. 'Іїі величності Зеріки Четвертої"”.

First of all, one can see how the subjects are willing to adapt available (from both internal and external sources) knowledge (about what 'a Phoenix' is or who 'Zerika' is) to the new situation but fail to do it due to the lack of information about the relevance of this knowledge for the new cultural context of both alternative reality and target culture. As a result, they feel some frustration which is clearly pronounced in Protocol \# 3: "It baffled me" and "I don't like it very much". Thus, the elements under consideration can be defined as 'frustrators' that stir the feeling of dissatisfaction even when the decision is made.

Adaptation in translation concerns not only the translator's behavior but also his/her mental structures that are being formed in the process of perceiving and interpreting different types of source signs. When we speak about translation into a native language, it would be natural to adjust new or alien to the target audience concepts in accordance with the translator's individual worldview as a representative of a certain culture and bearer of a corresponding mentality. At the same time, information that is to be translated into a new language and transfused into a new culture is, drawing on Andre Lefevere's metaphor, 'refracted', or, drawing on Mona Baker's metaphor, 'reframed' in the translator's mind in accordance with their ideas as to the specifics of a target audience's collective worldview. It also means that in a conceptual sense the strategy of domestication following which the translators are striving to adapt the mental image of a source text (or any of its components) in their minds to cognitive structures already present there (concepts, frames, scenes, etc.) helps them get over potential cognitive dissonance and thus can be regarded as a psychologically comfortable one. In this respect, let us consider the following example: "It was around mid-morning when I found the cave, hidden by a profusion of calia" (Brust, The Desecrator).

Our attraction here is drawn to such designation of time as 'mid-morning' which seems quite natural for the collective worldview of English-speaking individuals judging by such similarly-coined lexemes as 'midnight', 'midday', 
'midafternoon', 'midweek', 'midyear', etc. For Ukrainian speakers, on the contrary, such segmentation of time periods is less obvious, since there are only two Ukrainian designations of this kind we could think of - 'полуніч' for 'midnight' and 'полудень' for 'midday'. As a result, the subjects articulate their discomfort caused by the necessity to find the adequate form of reproducing this alien idea. See, for instance, protocol \# 1: "Mid-morning - 'всередині ранку'. 'Рано вранці', 'пізно вранці', 'всередині ранку' немає. Хай буде 'вранці'”.

Protocol \# 3: "Mid-morning - я розумію, що це середина ранку (це десь 10, 9 годин), наприклад, мені не зрозуміло, якщо чесно... можна взагалі нічого не писати, тому що це неважливо <...>. Можна написати 'був ВЖЕ ранок', тобто не 'ще' чи 'тільки', а вже середина, що нам і потрібно - 'був вже ранок”.

Protocol \# 6: “Так, что такое mid-morning можно себе представить, но не совсем понятно, как это выразить, потому что 'середина утра' тоже не звучит. Можно сказать просто 'наступного ранку'”.

The subjects opted for the same strategy of coping with the problem - they simply skipped the information that didn't fit into the familiar frame of time segmentation and stopped at the 'the next morning' variant, which can be regarded as cognitive adaptation.

Association is our $2^{\text {nd }}$ psycho-cognitive mechanism (in case of association the line between cognition and behavior is often blurred) of translation. If "associations are defined as complex representations that comprise unqualified relations between elementary representations" (Moors, 2014, p. 25), the associative mechanism can be characterized "as the activation of an association in memory" (ibid.). But more importantly, activated associations may have significant effect on performing all kinds of tasks, in our case - selecting the strategy and/or method of translation. According to Alexandra Zalevskaya, "the principle of associating as establishing connections of different types acts as one of the leading characteristics of human speech functioning which gives grounds to speak about the universality of the association mechanism" (Залевская, 1999, с. 51).

The role of association in the translator's decision-making is twofold. Firstly, the translator is expected to detect ('to catch') the associations embedded into the original by the author, or, in other words, to try to understand what associations underlay the author's decisions. At first glance, this task seems to be of a purely metempsychotic nature, although a closer look at it allows to make an exception for associations (more or less) clearly verbalized in the text or those referred to by the author in all kinds of paratexts. Secondly, the translator's decisions may stem from their own associations. Obviously, TAPs provide us with the second type of association-related information that serves as a powerful insight into the translator's decision-making.

On the other hand, author-related and translator-related associations are interwoven, since trying to get to the former ones the translator may inspire the latter ones which may or may not lead to a correct decision. As a rule, the translator's excessive passion for their own associations results in the introduction into the translated text of information never intended by the author. As an example, 
we can once again refer to the above case of the name 'Zerika', falsely associated with English 'zero'. Luckily, in this case the subjects' assumptions did not yield any wrong translations. Unfortunately, this was not the case with the following example: "My next ride was on a wagon drawn by a pair of oxen. This was from a merchant, a Jhegaala" (Brust, The Desecrator).

The problem was caused by the quasi-realia 'Jhegaala' whose reference was quite opaque due to the lack of the contextual explanatory markers as well as to the method of word-formation itself. Most probably, the nonce word was coined to denote a character's nationality/ethnicity or belonging to a social/professional group. In Protocol \# 5 we can see how the subject is trying to ascribe a meaning to the word proceeding from its phonetic resemblance to another word that is present in his/her mental lexicon: “Назва, яку я не знаю, перша асоціація - 'Джигало'. Якщо купець.....джигало - на русском 'бабник', купець може бути бабником, отже буде 'Жигало'. <...>. Дали таке йому ім'я, що можливо і вирішило його долю.....Я зупиняюсь на варіанті - “Жигало””.

The most interesting fact is that the word 'жиголо' (from French 'gigolo') that stirred the wrongful association in the translator's mind is misspelled in the Protocol and we can only guess if it's a genuine mistake or a subconscious desire to bring Brust's coinage closer to its imaginary Ukrainian prototype. To this, we can only add that the direct allusion to gigolo was not included into the final version of the translation, though the subject added the reference to the fact that 'Jhegaala' was the character's nickname which may be the consequence of the abovementioned considerations verbalized in the protocol: "Наступну свою подорож я провів за допомогою запряжених волів. Від купия, на прізвисько Жигало, який був досить балакучим".

This mistake is very interesting as it illustrates a rather typical course of action within which the translator freely adds to translation some (mis)information that was allegedly implied by the author. This type of behavior may be characterized with the help of a theatrical term 'gagging' in its negative meaning 'trying to do something that doesn't flow naturally from the scene' and is often instigated by false associations.

It looks like concurrent verbalizing is well suited for researching psychological and cognitive aspects of the translator's mistakes. Another type of association-based mistake is observed in cases when a particular linguistic element (mostly, a word) is associated with a particular referent so tightly that only one particular variant of translation is taken into account. Let us consider the following situation from the original: "My sword was light on my back, but the cross guard kept smacking the back of my head when I climbed down off rocks. I tried to adjust it, but couldn't find a position that worked" (Brust, The Desecrator).

The element in question in this context is 'guard' mistakenly interpreted as 'a person who keeps a protecting, supervising, or restraining watch or control over people' while in fact here it is part of a compound 'cross guard' meaning 'a bar of metal at right angles to the blade, placed between the blade and the hilt'. 
See, for instance, Protocol \# 4: “Якщо guards можна перекласти, як 'конвоїри', проте ми не знаємо, чи це справді конвоїри, можливо, потім ми змінимо цей момент. Якщо cross guard, можливо, guards було два, тому можна перекласти, як 'по обидва боки від нього'. Гм, couldn't adjust, але до чого, до того, guards kept smacking at his back? Можливо, слід перекласти, не як 'пристосуватись', а як 'звикнутись', що звучало б краще. Якщо перекласти 'я не міг знайти якийсь спосіб', або 'дійсний спосіб', то в тексті буде 'мало життя’, тобто, це не пасуватиме українській мові”.

The TAP demonstrates how initial association-based mistake is combined with other types of mistakes which eventually culminate in substituting a real sourcetext situation with a fictitious (farfetched) one. Cognition-wise, this case can be characterized as reframing. The mechanism of reframing can be presented as a sequence of mistakes: mistake 1 is caused by falsely associating 'guard' with a protecting/supervising person; mistake 2 is caused by falsely associating 'cross' with 'two intersecting lines' (as a result, the number of guards doubled); mistake 3 is caused by the assumption that two guards should be placed on both sides of the person they accompany, which is a clear case of adaptive 'gagging'; mistake 4 is caused by both false association (guards are associated with rude treatment of their detainees) and adaptation (guards are the ones who smack the hero on the back of his head).

In the end, the translator's imagination drew a picture in which two guards accompanied the hero on both sides smacking him periodically on the back of his head: "Я не відчував важкості свого меча за спиною, проте охоронці по обидва боки від мене час від часу ляскали мене ззаду, поки я спускався з гори. Я намагався звикнутись з иим, проте мені це так $і$ не вдалось". The fact that these 'guards' never surfaced in the text again didn't seem to bother the subject much.

The experiment proves that TAP can be a very fruitful technique for investigating mistakes in translation not from their linguistic or stylistic but from psycho-cognitive perspective, especially when the subjects lack experience and are prone to erroneous judgments. Such mistakes can be presented as a malfunction of a system, a sort of a glitch in the translator's thinking. What causes such glitches? Potential causes are manifold but our attention is drawn to those instances when faulty translations proceed from erroneous perception/interpretation of a source text elements. Presumably, such perceptions/interpretations are based on the same mechanisms that are responsible for correct ones. In other words, all the translator's decisions are driven by universal psycho-cognitive mechanisms which in case of errors get 'derailed'. Thus, we can speak about correct or incorrect adaptations, associations, etc.

One can also presume that the translator's decision-making is under a strong pressure from those mental formations - models, prototypes, stereotypes - that have been interwoven into an intricate associative verbal network in his/her mind concerning both genre/text/idiolect and specifics of its/their reproduction in the target language and culture. As a result, the translator's striving to adjust his/her 
decision-making in accordance with these mental formations reveals associative nature of this creative process. See, for instance, Protocol \# 2: "На жаль, у мене немає можливості отримати інформацію, щодо асоціацій від цих назв у носія мови, мабуть, деякі з них розраховані на те, що якісь історичні чи лінгвістичні реалії носіїв мови дають якусь додаткову інформацію, коли вони їх бачать, але я вважаю, що це теж такий стилістичний прийом автора, тому що у багатьох творах такого жанру - отже, це $є$ казка, якесь фентезі чи якийсь магічний твір, тобто, ми бачимо, що цей текст, безперечно, $є$ вигаданим, i для творів такого жанру досить часто характерні такі власні назви, які бувають дуже заплутаними, епічними, тому що це якось передає атмосферу цього магічного вигаданого світу, і якби вони були досить повсякденні, це було б, мабуть, нецікаве читачу і не відповідало тому впливу, який автор має на меті здійснити на свого читача".

Association as a mechanism that activates in memory a representation of a certain object as a reaction to another object is tied by a causal type of relation to analogy as a mechanism that "involves the transfer of relational information from a domain that already exists in memory (usually referred to as the source or base domain) to the domain to be explained (referred to as the target domain)" (Vosniadou, Ortony, 1989, p. 6). Analogical reasoning that leads to the translator's decision-making can take form of different similarity-based heuristics, among which the heuristic of representativeness is the most common one. As its name implies, this method of action proceeds from the idea of representativeness, that is "an assessment of the degree of correspondence between a sample and a population, an instance and a category, an act and an actor or, more generally, between an outcome and a model" (Tversky, Kahneman, 2002, p. 22). In most instances, representativeness can be likened to similarity which, in its turn, can be surface (i.e. 'perceptual') and deep ('underlying' or 'cognitive'). See, for instance Protocol \# 3 where association leads to similarity-based, representativeness-type analogical reasoning: “Indicate я так розумію це 'вияснить', 'подумать'... 'тебе не приходило в голову, що я поспішав'... немає сенсу, тут написано, що не було ніякого поспіху... 'тому я залишився в Адрилан...ці' (ну як 'ШріЛанка/ці') 'насолодитися цивілізацією””.

In this case, surface verbal association basing on vocal similarity 'Адріланка' - 'Шрі-Ланка' is followed by an analogical reasoning: if 'у Шрі-Ланці', then 'в Адріаланці'.

Protocol \# 4: ““Йолата' - цікаво, можна і 'Ялата' і 'Йолата'/'Йалата', але 'Ялата' схоже на Ялту, немає нічого незвичайного; 'Йолата' більш фентезійно і незвично звучить". Here again, first comes surface verbal association basing on vocal similarity 'Ялата' - 'Ялта', and then analogical reasoning: if 'Ялта' is a real toponym, similar to it 'Ялата' is not suitable for a fantasy work.

Heuristic of compatibility is another similarity-based method of action in the course of which the translator identifies compatible possibilities proceeding from prior experience. Orlando Espino and Ruth M. J. Byrne suggest that people tend to make decisions "based on an immediate heuristic"; they "make their judgment by 
envisaging initial possibilities, rather than fully thinking through all the possibilities" (Espino, Byrne, 2013, p. 127). In case of translation, this suggestion is illustrated by the number of alternatives translators get through before opting for the final one. Some of them are content with just a few while others browse through dozens of dictionaries in search of a perfect solution. See, for instance, Protocol \# 1: “Лише вранці'. Як же це, push, push bushes aside, push aside. Показати-то можна. push aside - 'отстранять'. Найтяжче описувати звичайні дії. 'Відгорнув', 'відділив', 'відкинув', 'відсунув', 'відштовхнув', 'відгорнув'. 'Відділив', 'від...' 'Відсунути', 'відкраяти'. 'Відмежувати', 'відвести'. Кусти - 'розгорнути', 'розчахнути'. Що ж мені зробити з ними?”

\section{Conclusion}

The analysis of information contained in TAPs of 6 semi-professional translators, subjects of the introspective experiment, together with translated texts themselves allowed to elicit some indirect but nevertheless illuminating information as to the role of adaptation, association and analogy in the translator's decision-making. Adaptation, association and analogy are portrayed as both cognitive procedures and psychological mechanisms whose combined action provides for successful resolution of problem situations in translation. On the psychological level, adaptation is seen as a mechanism that leads the translator to the state of adaptivity by applying available knowledge to new situations. On the cognitive level, adaptation implies adjusting new or alien to the target audience concepts in accordance with the translator's individual worldview as a representative of a certain culture. Association, whose cognitive and psychological aspects are tightly interwoven, has a double function in the translator's decisionmaking. On the one hand, the translator is expected to uncover and then reproduce the author's associations in the source text; on the other hand, the translator's decisions are often made under the influence of their own associations. Finally, association is causatively related to analogy - psycho-cognitive mechanism of transferring information from one object (sign) to another. Analogical reasonings channel the translator's decision-making through similarity-based heuristics, like representativeness and compatibility ones.

\section{References}

Демецька В. Адаптивна модель перекладу в психолінгвістичному вимірі. Psycholinguistics. 2019. № 26 (2). C. 71-90. https://doi.org/10.31470/2309-1797-2019-26-2-70-90

Залевская А. А. Введение в психолингвистику: Учебник. М.: Российск. гос. гуманит. ун-т., 1999.

Засєкіна Л.В., Засєкін С.В. Вступ до психолінгвістики: Навчальний посібник. Острог: Видавництво Національного університету “Острозька академія”, 2002.

Налчаджян А. А. Психологическая адаптация: механизмы и стратегии. 2-е изд., перераб. и доп. М.: Эксмо, 2009.

Ericsson, K. A. (2003). Valid and Non-reactive Verbalization of Thoughts during Performance of Tasks: Toward a Solution to the Central Problems of Introspection as a Source of Scientific Data. Journal of Consciousness Studies, 10, 1-18. 
Ericsson, K. A., Simon, H. A. (1987). Verbal Reports on Thinking. In: Introspection in Second Language Research. Multilingual Matters 30. (pp. 24-53). K. Faerch, G. Kasper (eds.). Clevedon: Multilingual Matters.

Espino, O., Byrne, R. (2013). The compatibility heuristic in non-categorical hypothetical reasoning: Inferences between conditionals and disjunctions. Cognitive psychology, 67, 98129. http://dx.doi.org/10.1016/j.cogpsych.2013.05.002

Jones, F. R. (2007). Unlocking the Black Box: Researching Poetry Translation Processes. In: Translation and Creativity. Perspectives on Creative Writing and Translation Studies, (pp.: 59-74). E. Loffredo, M. Perteghella (Eds.). London: Continuum. https://doi.org/10.5007/2175-7968.2009v1n23p171

Levý, J. (2000). Translation as a Decision Process. In The Translation Studies Reader. (pp. 148159). L. Venuti (ed.). London, New York: Routledge.

Milton, J. (2009). Translation Studies and Adaptation Studies. In Translation Research Projects 2. (pp. 51-58). A. Pym, A. Perekrestenko (Eds.). Tarragona: Intercultural Studies Group.

Moors, A. (2014). Examining the Mapping Problem in Dual-Process Models. In Dual-Process Theories of the Social Mind. (pp. 20-34). J. W. Sherman, B. Gawronski, Y. Trope (Eds.). New York / London: The Guilford Press.

Reiss, K. (2000). Type, kind and individuality of text. Decision making in translation. In The Translation Studies Reader. (pp. 160-171). L. Venuti (ed.). London, New York: Routledge.

Rojo, A. (2015). Translation Meets Cognitive Science: The Imprint of Translation on Cognitive Processing. Multilingua: Journal of Cross-Cultural and Interlanguage Communication, 34 (6), 721-746. https://doi.org/10.1515/multi-2014-0066

Schulkin, J. (2009). Cognitive Adaptation. A Pragmatic Perspective. Cambridge: Cambridge University Press. https://doi.org/10.1163/18758185-90000175

Tasse, M. J. (2013). Adaptive Behavior. The Oxford Handbook of Positive Psychology and Disability.

Retrieved from https://www.oxfordhandbooks.com/view/10.1093/oxfordhb/9780195398786.001.0001/oxfo rdhb-9780195398786-e-001 https://doi.org/10.1093/oxfordhb/9780195398786.013.013.0009

Tversky, A., Kahneman, D. (2002). Extensional versus Intuitive Reasoning: The Conjunction Fallacy in Probability Judgment. In: Heuristics and biases: The psychology of intuitive judgment. (pp. 19-48). T. Gilovich, D. Griffin, D. Kahneman (eds.). Cambridge: Cambridge University Press. https://doi.org/10.1017/CBO9780511808098

Vinay, J.-P., Darbelnet, J. (1995). Comparative Stylistics of French and English. Amsterdam / Philadelphia: John Benjamins Publishing Company. https://doi.org/10.1075/btl.11

Vosniadou, S., Ortony, A. (1989). Similarity and analogical reasoning: a synthesis. In: Similarity and analogical reasoning. (pp. 1-18). S. Vosniadou, A. Ortony (eds.). Cambridge: Cambridge University Press. https://doi.org/10.1017/CBO9780511529863

\section{References (translated and transliterated)}

Demetska, V. (2019). Adaptyvna model perekladu v psykholingvistychnomu vymiri [Adaptive Model in Translation: Psycholinguistic Dimension]. Psycholinguistics, 26(2). 71-90. https://doi.org/10.31470/2309-1797-2019-26-2-70-90

Ericsson, K. A. (2003). Valid and Non-reactive Verbalization of Thoughts during Performance of Tasks: Toward a Solution to the Central Problems of Introspection as a Source of Scientific Data. Journal of Consciousness Studies, 10, 1-18.

Ericsson, K. A., Simon, H. A. (1987). Verbal Reports on Thinking. In Introspection in Second Language Research. Multilingual Matters 30. (pp. 24-53). K. Faerch, G. Kasper (Eds.). Clevedon: Multilingual Matters. 
Espino, O., Byrne, R. (2013). The compatibility heuristic in non-categorical hypothetical reasoning: Inferences between conditionals and disjunctions. Cognitive Psychology, 67, 98129. http://dx.doi.org/10.1016/j.cogpsych.2013.05.002

Jones, F. R. (2007). Unlocking the Black Box: Researching Poetry Translation Processes. In: Translation and Creativity. Perspectives on Creative Writing and Translation Studies, (pp.: 59-74). E. Loffredo, M. Perteghella (Eds.). London: Continuum. https://doi.org/10.5007/2175-7968.2009v1n23p171

Levý, J. (2000). Translation as a Decision Process. In The Translation Studies Reader. (pp. 148159). L. Venuti (ed.). London, New York: Routledge.

Milton, J. (2009). Translation Studies and Adaptation Studies. In Translation Research Projects 2. (pp. 51-58). A. Pym, A. Perekrestenko (eds.).Tarragona: Intercultural Studies Group.

Moors, A. (2014). Examining the Mapping Problem in Dual-Process Models. In Dual-Process Theories of the Social Mind. (pp. 20-34). J. W. Sherman, B. Gawronski, Y. Trope (Eds.). New York / London: The Guilford Press.

Nalchadzhan, A. (2009) Psichologicheskaja adaptatsiya: mekhanizmy $i$ strategii [Psycholinguistic Adaptation: Mechanisms and Strategies]. Moscow: Exmo.

Reiss, K. (2000). Type, kind and individuality of text. Decision making in translation. In: The Translation Studies Reader. (pp. 160-171). L. Venuti (ed.). London, New York: Routledge.

Rojo, A. (2015). Translation Meets Cognitive Science: The Imprint of Translation on Cognitive Processing. Multilingua: Journal of Cross-Cultural and Interlanguage Communication, 34(6), 721-746. https://doi.org/10.1515/multi-2014-0066

Schulkin, J. (2009). Cognitive Adaptation. A Pragmatic Perspective. Cambridge: Cambridge University Press. https://doi.org/10.1163/18758185-90000175

Tasse, M. J. (2013). Adaptive Behavior. The Oxford Handbook of Positive Psychology and Disability.

Retrieved

from https://www.oxfordhandbooks.com/view/10.1093/oxfordhb/9780195398786.001.0001/oxfo rdhb-9780195398786-e-001 https://doi.org/10.1093/oxfordhb/9780195398786.013.013.0009

Tversky, A., Kahneman, D. (2002). Extensional versus Intuitive Reasoning: The Conjunction Fallacy in Probability Judgment. In: Heuristics and biases: The psychology of intuitive judgment. (pp. 19-48). T. Gilovich, D. Griffin, D. Kahneman (Eds.). Cambridge: Cambridge University Press. https://doi.org/10.1017/CBO9780511808098

Vinay, J.-P., Darbelnet, J. (1995). Comparative Stylistics of French and English. Amsterdam / Philadelphia: John Benjamins Publishing Company. https://doi.org/10.1075/btl.11

Vosniadou, S., Ortony, A. (1989). Similarity and analogical reasoning: a synthesis. In Similarity and analogical reasoning. (pp. 1-18). S. Vosniadou, A. Ortony (Eds.). Cambridge: Cambridge University Press. https://doi.org/10.1017/CBO9780511529863

Zalevskaya, A. (1999). Vvedenie v psikholingvistiku [Introduction to Psycholinguistics]. Moscow: Russian State University for the Humanities.

Zasiekina, L., Zasiekin S. (2002) Vstup do psykholingvistyky [Introduction to Psycholinguistics]. Ostroh: National University "Ostroh Academy".

\section{Source}

Brust, S. (2011). The Desecrator. Retrieved from https://www.tor.com/2011/03/02/the-desecrator 